\title{
9/11 UND die Folgen IN DER PopmusiK I. TON-SPUREN
}

\author{
Thomas Phleps
}

\section{REMIXES}

Eine der ersten musikbezogenen Reaktionen nach 9/11 war die Produktion von Remixes, die in diesem Falle nicht Musik vermischten, sondern Musik und O-Töne der Berichterstattung am Tage der Anschläge. Im deutschsprachigen Raum hatte die SynthPop-Band And One ihr Doku-Remix »Amerika brennt « am 15. September als »aktuelles Zeitdokument « und »um unsere Wut zu verewigen« ins Netz gestellt: eine hart an der Peinlichkeitsgrenze angesiedelte Collage aus Nachrichtensplittern, Augenzeugenberichten, George W. Bush-Worten, Sinatras »New York, New York«, wabernden Sphären-Keyboards und zackigen Beats - laut Selbstaussage »für all die [...], die ihren Weg der Verzweiflung mit uns gehen wollen und die Tanzfläche als ein Medium der Hoffnung verstehen« (http://www.andone.com). In den USA wurden Doku-Remixes vor allem von den Radio- und Fernsehstationen (hier noch gekoppelt mit den allbekannten Bildern - vorgeblich der Trauer und Hoffnung) produziert.

Innerhalb kürzester Zeit schwirrten an die 100 dieser Remixes durch den Äther, darunter mehrere Bearbeitungen von John Lennons »Imagine «, einem Song, der nach 9/11 zunächst auf der Clear Channel-Liste fragwürdiger Texte (s.u.) auftauchte (und außerdem am 21. September 2001 beim größten Auflauf populärer Künstler, dem in New York und Los Angeles parallel veranstalteten und von über 8000 Fernseh- und Radiostationen live übertragenen Benefizkonzert $A$ Tribute To Heroes, überraschenderweise von Neil Young interpretiert wurde - dem Manne also, der wenig später mit seinem kriegerischen »Let's Roll« höchstpersönlich die letzten Insignien einer pazifistischgewaltfreien Popmusik aus dem Wege räumte).

Eines der vielen »Imagine«-Remixes zeigt an, dass hier vielfach mit heißer Nadel gestrickt wurde bzw. so unfreiwillig fragwürdige Textcollagen 
oder besser Textkollisionen wie »[Lennon:] Imagine all the people -/[Radiosprecher:] crashing into the second tower « in Kauf genommen wurden. Von ähnlichem Zuschnitt auch die Verknüpfung der Stimmen von John F. Kennedy, Dubya Bush und Sgt. Hartman (aus dem Kriegsfilm Full Metal Jacket) mit Musik und Text von Metallicas "Don't Tread On Me«.

Auf andere Weise in Kauf genommen wurde - bei den bekanntesten Remixes zumindest - die Erhöhung der Verkaufszahlen: so bei der Schmusenummer »Overcome des am 17. September 2001 erschienenen Albums $V$ der US-Band Live, das nicht nur mit O-Tönen vermischt, sondern zugleich zur musikalischen Untermalung eines von CameraPlanet.com produzierten Videos über die WTC-Bergungsarbeiten hergenommen und weltweit gesendet wurde. Und so vor allem bei dem so genannten, von der Radiostation KIIS in Los Angeles produzierten »WTC-Remix « von »Only Time « der irischen Sängerin Enya, hüben wie drüben erhoben zur »inoffiziellen Trauerhymne für die Opfer der Terroranschläge « - so die offizielle Pressemitteilung der Enya-Plattenfirma WEA, die damit »unauthorisiert « meinte, aber angeblich aufgrund der besonderen Situation gegen den urheberrechtlichen Verstoß nichts unternahm (vgl. http://www.regio-press-medien.de/cd-tips.htm). Der kurz nach 9/11 auch bei bundesdeutschen Sendern in einer "German Version« auf heavy rotation laufende Song war bereits im November 2000 auf dem Enya-Album $A$ Day Without Rain erschienen, machte aber erst durch die Bearbeitungen von KIIS in Los Angeles und in der Folge zahlreicher Fernsehsender derart Furore, dass nicht allein eine »Only Time (Remix)《Single Ende November 2001 auf dem Markt reüssierte, sondern auch und vor allem das Album über Monate hinweg in den oberen Chartregionen verblieb.

Die massenhafte Verbreitung und der schnelle Erfolg dieser WTC-, 9/11resp. Attack on America-Remixes (alt-)bekannter Songs führte dazu, dass Dutzende von Interpreten ihre eigenen Songs mit O-Tönen vorzugsweise des George W. Bush garnierten - und daraufhin der Guerilla-Funk-Rapper und selbsternannte »Bush Killa« (1992: Bush sen.) Paris seine GegenpropagandaPropaganda »What Would You Do?« mit einem zynischen Bush-jun.-DokuFake einleitete: "Good evening, I would like to report on the state of our war against the American people...« (vgl. S. 122). 


\subsection{Einige WTC-, 9/11- resp. Attack on America-Remixes ${ }^{1}$}

3 Doors Down: »Duck And Run« (WTPT in Greenville) • Aerosmith: »Living On The Edge • Alabama: »American Pride« • And One: »Amerika brennt« • The Beatles: »Yesterday« • Blessid Union of Souls: »I Believe« • Garth Brooks: »The Dance « / »The Change« • Brooks \& Dunn: »Only In America« • Buffalo Springfield: »For What It's Worth" (WOFX) • Maria Carey: "Hero" (Clear Channel station) - Mariah Carey \& Boyz II Men: »One Sweet Day« • Ray Charles: "America The Beautiful« (WKMQ in Rockford) - Charlie Daniels Band: »In America " (WKHY in Lafayette) • Eric Clapton: »Tears In Heaven « (WMGK in Philadelphia) - Collective Soul: »The World I Know« (WZPL) • Cranberries: »Dreams « • Creed: »Higher « / »With Arms Wide Open $($ WYSP in Philadelphia) - Dalia: »Mother I Miss You« • Destiny's Child: »Emotions« • Neil Diamond: »Coming To America« • DJ Sammy: »Heaven « (KKXX-FM in Bakersfield, CA.) • Drowning Pool: »Bodies« • Enigma: »Return To Innocence« • Enya: »Only Time« (KIIS in Los Angeles) • Amy Grant: »I Will Remember You« • Lee Greenwood: "God Bless America« (WDMP in Dodgeville / Entercom in Milwaukee) • Jimi Hendrix: "The Wind Cries Mary" • Don Henley: "In A New York Minute" (WVRV in St. Louis / Radio Oldenzaal / Brown Bag Productions) - Faith Hill: "Star Spangled Banner" (KIIS in Los Angeles) - Whitney Houston: "Star Spangled Banner (WBBN in Chicago) • Enrique Iglesias: »Hero « (KZHT in Salt Lake City / WBBN in Chicago) • Michael Jackson: »Heal The World • Jewel: »Hands « (WHTZ in New York) • John Lennon: »Imagine« • Annie Lennox: »Why« (WVRV in St. Louis) • Linkin Park: „Crawling« • Live: „Overcome« (KMXB in Las Vegas / WKQX in Chicago) - Martina McBride: "Let Freedom Ring • Sarah McLachlan: »I Will Remember You« (KUDL in Kansas City) / »Dear God« / »Angel« (Clear Channel station) - Jo Dee Messina with Tim McGraw: »Bring On The Rain« (Clear Channel station) • Metallica: »Don't Tread On Me« / "Seek and Destroy« • Moby: »Porcelain« (WHFS in Washington) • Tom Pilcher: »God Bless The USA« (WVRV in St. Louis) • REM: »Everybody Hurts« (CKZZ in British Columbia) • LeAnn Rimes: »Please Remember Me« • Diamond Rio: »One More Day« • Skillet: »You Are My Hope« • Splender: »I Think God Can Explain" (WIOG in Saginaw) • Bruce Springsteen: »Born In The USA « (KDOT in Reno) - Sting: »Fragile« (WBOS in Boston) • Twisted Sisters: »We're Not Gonna Take It« • U2: »Peace On Earth« (Demodave at KOMP 92.3) / »Stuck In A Moment« (KIIS in Los Angeles) / »Seconds« • Mark Wills: »Wish You Were Here« • Neil Young: »Rockin' In The Free World«

1 Soweit bekannt, sind die für die Produktion verantwortlichen Radiostationen in Klammern angefügt. 


\section{Die Schwarze Liste von Clear Channel}

Direkt nach dem 11. September 2001 setzte Clear Channel Communications rund 150 »lyrically questionable «, textlich angeblich fragliche Popsongs auf den Index (s.u. und - beispielsweise - http://text.staticfree.info/banned_ songs.html). Clear Channel ist nicht irgendwer, sondern die größte Radiokanalkette der Welt mit rund 1200 Sendern in 47 US-Bundesstaaten und rund 240 Sendern nebst rund 20 Fernseh-Stationen in 63 anderen Ländern dieser Welt.

Man mag bei dieser Liste einiges der ersten und verständlichen Aufregung zuschreiben - z.B. Van Halens »Jump« oder Drowning Pools »Bodies« mit dem Refrain »Let the bodies hit the floor « - daran ist zunächst nichts Ungewöhnliches - sicherlich hat man hierzulande während der großen OderFlut 2002 auch nicht gerade Dalidas »Am Tag als der Regen kam« auf Rotation gesetzt. Befremdlicherweise sind auf der Clear Channel-Liste aber neben gerade noch Zuschreibbarem wie »Ruby Tuesday « von den Stones eine große Anzahl an Antikriegsliedern zumal aus der Zeit des Vietnamkrieges versammelt (u.a. The Doors: »The End«; Edwin Starr: »War«; Black Sabbath: »War Pigs«; Barry McGuire: »Eve Of Destruction«) und des Weiteren Songs, die eindeutig nur auf dieser schwarzen Liste stehen, weil ihre Interpreten die falsche Ideologie - so Rage Against The Machine und zwar (als einzige) »all songs « - oder die falsche Religionszugehörigkeit haben - so System Of A Down (auf der Liste »Chop Suey«) und Cat Stevens, der vor Jahren schon zum Islam konvertierte und sich seitdem Yusuf Islam nennt (auf der Liste »Peace Train« und »Morning Has Broken«).

Selbstverständlich wurde wenige Tage später von offizieller Seite vehement dementiert, dass Clear Channel auch nur einen Song aus dem Airplay strich: Das Ganze sei ein Fake, ein Gerücht und allenfalls habe irgendein Programmdirektor irgendwo in Kalifornien eine private Liste zusammengestellt und rumgereicht (siehe Clear Channel-Sprecherinnen Pam Taylor in »Banned Songlist Revealed as Fake. « In: The Guardian, 20. September 2001 [http://www.guardian.co.uk/wtccrash/story/0,1300,555061,00.html] und Rebecca Allmon in Michael Bertin: »The Music Business in a Post-911 World: Imagine. «In: Austin Chronicle 21, Nr. 13, 30. November 2001 [http://www. austinchronicle.com/issues/dispatch/2001-11-30/music_feature.html]).

Auf jeden Fall aber hat sich, Wer-auch-immer diese offiziell nicht existierende Liste ausdachte, etwas dabei gedacht: Bei der textlich harm- und musikalisch (Entschuldigung:) trostlosen Beatles-Nummer »Ob-La-Di, Ob-La- 
$\mathrm{Da} \ll$ z.B. die verschwörungstheoretisch exquisite Auskunft: Ob-La-Di gleich O-B-L oder O-B-Ladi gleich Osama-Bin-Ladin.

Über solche Songs sollten wir tatsächlich zweimal nachdenken (»songs we should think twice about «), empfahl - während noch eifrig dementiert wurde - der Folksänger John McCutcheon in seinem am 19. September 2001 komponierten Song »The List« (http://www.folkmusic.com/f_music.htm). Nicht ganz im Stile von Oskar Maria Grafs »Verbrennt mich!« (1933) fragt sich McCutcheon - Dylan und vieles mehr zitierend -, »womit [er] diese Schmach verdient « habe, nicht auf der Liste zu erscheinen: »How many songs must a folksinger write / Before they're forever banned?«

\subsection{Clear Channel's List of Songs with Questionable Lyrics}

311: »Down« 3 Doors Down: »Duck And Run« • AC/DC: »Shot Down In Flames« / "Shoot To Thrill« / »Dirty Deeds« / »Highway To Hell« / »Safe In New York City« / »TNT« / »Hell's Bells« • Ad Libs: »The Boy From New York City« • Alice In Chains: »Rooster« / »Sea Of Sorrow « / »Down In A Hole« / »Them Bone« • Alien Ant Farm: »Smooth Criminal« • Animals: »We Gotta Get Out Of This Place« • Louis Armstrong: »What A Wonderful World« • Bangles: »Walk Like An Egyptian« • Barenaked Ladies: »Falling For The First Time« • Beastie Boys: "Sure Shot / "Sabotage« • The Beatles: »A Day In The Life« • The Beatles: »Lucy In The Sky With Diamonds« / »Ticket To Ride« / »Ob-La-Di, ObLa-Da« • Pat Benatar: »Hit Me With Your Best Shot« / »Love Is A Battlefield « Black Sabbath: »War Pigs« / "Sabbath Bloody Sabbath« / »Suicide Solution« • Blood Sweat \& Tears: »And When I Die« • Blue Oyster Cult: »Burnin' For You« • Boston: "Smokin« • Brooklyn Bridge: »Worst That Could Happen« • Arthur Brown: »Fire« - Jackson Brown: »Doctor My Eyes« • Buddy Holly \& The Crickets: »That'll Be The Day« • Bush: »Speed Kills« • Cat Stevens: »Peace Train« / »Morning Has Broken« • Chi-Lites: »Have You Seen Her« • Petula Clark: »A Sign Of The Times« $\bullet$ The Clash: »Rock The Casbah« $\bullet$ Phil Collins: »In The Air Tonight « Sam Cooke: »Wonderful World« • Creedence Clearwater Revival: »Travelin' Band « $\bullet$ The Cult: »Fire Woman« • Bobby Darin: »Mack The Knife« • Dave Clark Five: »Bits And Pieces« • Dave Matthews Band: „Crash Into Me« • Neil Diamond: »America« • Dio: »Holy Diver« • Drifters: »On Broadway« • The Doors: »The End « Drowning Pool: »Bodies« • Bob Dylan: »Knockin' On Heaven's Door « Everclear: »Santa Monica« • Shelly Fabares: »Johnny Angel« • Filter: »Hey Man, Nice Shot « Fontella Bass: »Rescue Me« • Foo Fighters: »Learn To Fly« • Fuel: »Bad Day« • Peter Gabriel: »When You're Falling« • The Gap Band: »You Dropped A Bomb On Me« • Godsmack: »Bad Religion« • Norman Greenbaum: "Spirit In The Sky« • Green Day: »Brain Stew« • Guns N Roses: »Knockin' On Heaven's Door« • Happenings: »See You In September« • Jimi Hendrix: »Hey Joe« • Herman's Hermits: »Wonder World« • Hollies: »He Ain't 
Heavy, He's My Brother« • Jan \& Dean: »Dead Man's Curve« • Billy Joel: »Only The Good Die Young • Elton John: »Benny \& The Jets« / »Daniel« / »Rocket Man« • Judas Priest: «Some Heads Are Gonna Roll« • Kansas: »Dust In The Wind « Carole King: »I Feel The Earth Move« $\bullet$ Korn: »Falling Away From Me« - Lenny Kravitz: »Fly Away« • Led Zeppelin: »Stairway To Heaven« • Jerry Lee Lewis: »Great Balls Of Fire« • John Lennon: »Imagine« • Limp Bizkit: »Break Stuff « Local H: »Bound For The Floor« • Los Bravos: »Black Is Black« • Lynyrd Skynyrd: »Tuesday's Gone« • Martha \& The Vandellas: »Nowhere To Run« / »Dancing In The Streets« • Paul McCartney \& Wings: »Live And Let Die« • Barry McGuire: »Eve Of Destruction« • Don McLean: »American Pie« • Megadeth: »Dread And The Fugitive« / »Sweating Bullets« • John Mellencamp: »Crumbling Down« / »I'm On Fire« • Metallica: »Seek And Destroy« / »Harvester Or Sorrow « / »Enter Sandman« / »Fade To Black« • Steve Miller: »Jet Airliner « Alanis Morissette: »Ironic« • Mudvayne: »Death Blooms« • Rickey Nelson: »Travelin' Man« • Nena: »99 Red Balloons« • Nine Inch Nails: »Head Like a Hole« • Oingo Boingo: »Dead Man's Party« • P.O.D.: »Boom« • Paper Lace: »The Night Chicago Died « John Parr: »St. Elmo's Fire« • Peter \& Gordon: »I Go To Pieces« / »A World Without Love« • Peter Paul \& Mary: »Blowin' In The Wind « / »Leavin' On A Jet Plane« • Tom Petty: »Free Fallin'« • Pink Floyd: »Run Like Hell« / »Mother « Elvis Presley: »(You're The) Devil In Disguise« • Pretenders: »My City Was Gone« • Queen: »Another One Bites The Dust « / »Killer Queen« • Rage Against The Machine: All songs • Red Hot Chili Peppers: »Aeroplane« / »Under The Bridge« • R.E.M.: »It's The End Of The World As We Know It« • Rolling Stones: »Ruby Tuesday« • Mitch Ryder \& The Detroit Wheels: »Devil With The Blue Dress" • Saliva: »Click Click Boom« • Santana: »Evil Ways« • Savage Garden: »Crash And Burn« • Simon \& Garfunkel: »Bridge Over Troubled Water« • Frank Sinatra: »New York, New York« • Skeeter Davis: »End Of The World« • Slipknot: »Left Behind, Wait And Bleed« • Smashing Pumpkins: »Bullet With Butterfly Wings« • Soundgarden: »Blow Up The Outside World « / »Fell On Black Days« / »Black Hole Sun« • Bruce Springsteen: »I'm On Fire« / »Goin' Down« / »War« • Edwin Starr: »War« • Steam: »Na Na Na Na Hey Hey« - Stone Temple Pilots: »Big Bang Baby« • Stone Temple Pilots: »Dead \& Bloated « - Sugar Ray: »Fly« • Surfaris: »Wipeout« • System Of A Down: »Chop Suey!« • Talking Heads: »Burning Down The House« • James Taylor: »Fire And Rain« • Temple Of The Dog: »Say Hello To Heaven« • Third Eye Blind: »Jumper« • Tool: »Intolerance« • Tramps: »Disco Inferno« • U2: »Sunday Bloody Sunday« • Van Halen: »Jump« / »Dancing In The Streets« • J. Frank Wilson: »Last Kiss« • Zager and Evans: »In The Year 2525« • Young-bloods: »Get Together« • Zombies: »She's Not There« 


\section{3. »Flight $93 \ll$ Songs}

»The defiant words >Let's Roll s spoken by Todd Beamer to the men under his command are simple but convey a scall to arms like no other phrase. The words have come to symbolize American courage and resolve. It is a call that none of us will ever hear without recalling the events of that haunting day. It is a phrase that has come to mean, we are a nation ready to defend its freedom. And defend it, we must! (Chris Curtis: »Let's Roll for Freedom.« In: BellaOnline, The Voice of Women, http://www.bellaonline.com/articles/ art5125.asp).

Flug 93 von United Airlines, der am 11. September 2001 mit 37 Passagieren und 7 Besatzungsmitgliedern an Bord vom Flughafen Newark bei New York City mit 41 Minuten Verspätung kurz vor 9 Uhr morgens startete, hatte vier Terroristen an Bord, die recht bald die Gewalt über die Maschine an sich brachten. Aus den verzweifelten Telefonanrufen der Passagiere und Flugbegleiter ging hervor, dass sie mit Teppichmessern die Crew und die Fluggäste bedrohten. Was tatsächlich an Bord der entführten Boeing 757 geschah, ist trotz der Gesprächsmitschnitte nicht widerspruchsfrei zu erschließen. Jedenfalls stürzte die Maschine in der Nähe von Shanksville, Pennsylvania, ab, nachdem »40 brave souls « - wie es auf der Seite des Flight 93 Memorial Information Center (http://www.shanksvillememorial.com) geschrieben steht - gekämpft hatten gegen »armed terrorists to save the lives of others «. Unter diesen braven Seelen »the Bravest«, der wahre Held: Todd Beamer, ein 32jähriger account manager sprich Buchhalter aus Cranbury, New Jersey, dessen letzte Worte (eines angeblich 13minütigen Telefongesprächs!) von Bord zu einer Art Symbol des saktiven Widerstands gegen den Terror und recht bald zum »call to arms«, zum Kriegsruf der Patrioten wurden:

»Are you guys ready? Let's roll!«

Jeff Baker: »Flight 93 Song« • Jennifer Baldwin: »He Never Came Back« • The Bellamy Brothers: »Let's Roll America« • Blue Sage: »Flight 93« • C. Daniel Boling: »Flight 93: I Just Called To Say Goodbye« • dcTalk: »Let's Roll« • Carl Dorsey \& Friends: »Thank You Flight 93« • Dusty Drake: »One Last Time« • Catherine Faber: »United 93« • Leslie Fish: »Flight 93« • Frontier Galaxies: »Flight $>93$ • Gashouse feat. Tony Priscaro: »God Bless The USA 2001« • David Kendall Grant: »Kabul To Manhattan, Boys Of Flight 93« • Russ Grimm: »Roll On« • Grumbletummy: »Silent Vigil For The Missing « Blake Hodgetts: »The Heroes of Flight 93 • Kristy Jackson: »Little Did She Know (She'd Kissed A Hero)« • David Laurence: »Heroes Of Flight UA 93« • Bobby Leeds: »Airliner 
93« • Bruce Maccabee: »The Ballad Of 911« • Mark A. Mandel: »No Safe Ground « Larry Martin: »Flight Number Ninety-Three« • Shane Minor: »Don't Ask Why« • Johnny Moore: »Flight 93« • NikiVee: »Flight 93« • Oxygenhose: »Flight 93« • Paper Thin: »9/12 (Never Forget)« • Barry Preston: »Let's Roll« • Bette C. Ross: »America The Beautiful« • Eric Schrieber: »They Did What Had To Be« • Singers of Mad River Chorale: »Flight 93: The Spirit Of America« • Steve Stephenson: »Heroes Of Flight 93« • Mick Terry: »If We're Going Down (United Flight 93)« • Tony and Shanne: »Let's Roll, America« v Twin Hearts: »Flight 93 >American Hero « - Various Artists: Let's Roll: Together in Unity, Faith and Hope (CD, benefiting the Todd M. Beamer Foundation) • Neil Young: »Let's Roll«

\section{MP3-Sammlungen}

In der Folge von 9/11 stellten nicht nur zahlreiche Interpreten vorzugsweise aus dem Amateur- bis Semiprofibereich ihre wie-auch-immer auf die Ereignisse bezogenen Musikproduktionen über Internetportale ins Netz, sondern wurde auch eine Vielzahl an Song- resp. MP3-Sammlungen unter Überschriften wie »In Memory of September 11«, »Music inspired by September 11 « oder »World Trade Center Commemoration« zum Anhören und/oder Downloaden bereitgestellt. Von thematisch eindeutigen Kompilationen wie »911 Rot in Hell Osama!« (http://stations.mp3s.com/stations/245/911_rot_ in_hell_osama_.html) reichte die Bandbreite bis hin zu "Songs Created in Songwriting Workshops « (http://www.bobreidmusic.com/911.htm) oder regional Verortetem wie »lowa Artists Respond 9/11« (http://www.iptv. org/lii/extra/1203_artists.cfm). Mitte 2002 gab es allein beim größten Portal für frei verfügbare Musik, MP3.com, rund 250 dieser 9/11-bezogenen "Stations « mit weit über 1000 Songs, außerdem über 50 weitere zum Osama bin Laden- und Taliban-Komplex mit um die 400 Songs.

Im Dezember 2003 wurde MP3.com von Universal an den US-amerikanischen Computer-Newsdienst CNET verkauft. Da CNET - laut eigenen Angaben - mit dem Kauf nur die Rechte an der Domain, nicht aber die Inhalte erworben hat, steht seit dem 2. Dezember 2003 das in über sechs Jahren akkumulierte Musik-Archiv von 750.000 frei verfügbaren Titeln unabhängiger Interpreten nicht mehr zur Verfügung. Auch die nachfolgend beispielhaft angeführte MP3.com-Station "Songs of the World Trade Center Disaster « (http://stations.mp3s.com/stations/226/songs_of_the_world_trade_cente. html) ist seit Ende 2003 nicht mehr online, aber einige der Songs sind über die Homepages der Interpreten oder andere Musikportale weiterhin zugänglich. 


\subsection{Songs of the World Trade Center Disaster}

»This station is, as far as I'm aware, the Internet's largest collection of songs with lyrics written specifically about the events of September 11, 2001 and the declaration of a War on Terrorism. You will find many different viewpoints and musical styles here, but each song is a musical response to this moment in America's history. Last updated September 10, 2002. Maintained by the administrator of Cybersongs Radio« (http://stations.mp3s.com/stations/226/ songs_of_the_world_trade_cente.html).

Aliens Among Us: »Be Strong (World Trade Center Tribute)« [Country] • Shane Avery: »A Song of America 9-11-2001« [Country] • Nick Baker: »Here's To Our Heroes (9-11 Tribute Song) « [Pop] • Band Name Hollow: "American Pride« [Pop] • Robin Barrett: »Track 'Em Down« [Blues Rock] • Deborah Bishop: »Red, White, And Blue« • C. Daniel Boling: »Flight 93 (I Just Called To Say Goodbye)« [Folk] • bpurple: »Let Me Find You Today« [Folk] • Mark Bracich: »You Lose« [Rock] • Call Me Alice: »We Grow Stronger « [Pop] • Bill Cane: »Twin Towers« [Country] - Colletta: "Surviving September 11th, 2001« [Pop] - Scott Crazy: »Taliban Two-Step« [Metal] • Brian Allen Curtis: »And The Banner Yet Waves (911-01 Tribute)« [Country] • Cynic Guru: »Catastrophe« [Indie] • Donny Daley: »Osama B.L., You're Gonna Get What's Comin'« [Rock] • Dorsey: »9-11-01« [Pop/Folk] • Kevin Duggan: »Osama Blues« [Acoustic Blues] • Eden (Atlanta): »Sept. 11 -I Will Not Lie Down« [Alternative] • David Elias: »And I Said « [Folk] - Paul Epstein: »9-1-1« [Folk] • M. Everitt: »Hey Osama« [Country] • Faraday's Dog: »Twin Towers « [Pop] • Fernando: »Give Him Up Taliban« [Pop] • Linda Finkle: »Are You With Us (September 11th Anthem)« [Rock] • Ellyn Fleming: „Crying Over New York City« [Soft Rock] • Glitter N Gold: »America (September 11, 2001 Fight Song)« [Pop] • Goldfinger Mest GoodCharlotte: »The Innocent« • Steve Good: »Osama Bin Rotten« [^Political Humor«] • Goodnight Twin Towers: »Goodnight Twin Towers « [Pop] • Jon Gowen: »Send Osama To Texas« [Country] • David Kendall Grant: »Kabul To Manhattan, Boys Of Flight 93« [Folk] - Colleen Gray: "Say A Prayer« [Folk] - Jeff Alan Greenway: »Memoriam (Please Stop) « [Pop] • Tom Hokanson: »Freedom Train« [Folk] • Jeff Horwich: »9-11-01 « [Folk] • J. R. Hoye: »America, Awakened« [Rock] • Dave Isaacs: »Here On This Shore« [Rock] • Julia and Laurie: »A Rose For September « [Folk] - Justina: »Free To Be« [Pop] • Elly K: »Innocence (WTC September 11, 2001)« [Pop] • Kast-One: »9-1-1 (9-11-01 Tragedy)« [HipHop] • Dave Kelldorf: »Help Me (World Trade Center)« [Soft Rock] • David Kilpatrick: »Ground Zero« [Folk] • Sarah Marie Klaren: »1000 Angels« [Soft Rock] • Knuckleball Knorton: »Ballad Of Osama« [Parodie »I Came From Alabama«] • Richie L.: »In The Sky (September 11, 2001 Tribute) « [Pop] • L8 Bloomer: »We're Still America (Twin Towers)« [Pop] • John Land: »We The People (September 11, 2001)« [Folk Rock] - Laurie Larson: »On This Day« [Folk] • Forrest Lee Jr: »America Strikes Back« 
[Country] • Forrest Lee Jr.: »God Bless America (9-11-2001 Tragedy)« [Country] • Vicki Lee: »Angels On Golden Wings « [Pop] • Fresh Lettuce: »9-1-1« [Rock] • Lisa D. MacDonald: »Find A Way (To Say I Love You)« [Soft Rock] - Frances Mai-Ling: »Tuesday's Mourning (September 11, 2001)« [Piano] • Fani Mancini: "Stand Up For The USA (9-11 Tribute Song)« [Country] • Ron Marler: »9-11« [Rock] - Curtis Mathews: "America Stands Tall« [Pop] - Rezah \& Nick Matthews: »Hole In The Sky (September 11th Tribute)« [Folk] - MC Epitome: »2001 (11th Sept. 01 And Aaliyah Tribute) [HipHop] • Bobby McBride: "September 11th - Our Holiday « [Folk] • Barbi McCulloch: »They Can't Take Our Love« [Pop] • Loren McDonald aka MisterrMac: »We Are America« [Pop] • Steve McGregory: »As The Firemen Ride« [Country] - MONTY: »America Rocks« [Rock] • Mystic Cowboys: »Rebuilding America (9-11-2001 Tribute)« [Country Rock] - Natural Phenomenon Ocean: »The U.S.A. Is A-Okay!« [Country] • OneFiveFour: »Osama Sleeps Tonight« [Parodie »The Lion Sleeps Tonight «] • Phimosis »Osama Bin Laden «: »Osama Bin Laden« [Dance] • John Malcolm Penn: »The Osama Waltz« [`Political Humor`] • Frank Persico: »Hold On (A Tribute To The World Trade Center)« [Folk] - Pittsburgh Artists Combatting Terrorism: "God's Gonna Cry« [Rock] • Dick Price: »Osama Bin Laden« [>Political Humor`] • Frank Princiotta: »Heart Rock: »Masters Of Hate (911-2001)« [Pop] • Mike Przygoda: »Help!« [Acoustic Pop] • Dolly Rappaport: »How Could This Happen? 9-11-01 « [Soft Rock] • Rdub: »9-11-01 « [Folk] • Sandy Ross: "September 11th « [Folk] • David Rovics: »Dying Firefighter « [Folk] • Jim Russ: »The American Way « [Pop] • Richie Saccente \& Juice: »Build It Higher« [Tropical] • Danny Schmidt: »Tick Tock« / »Already Done« [Folk] • John Henry Sheridan: "Anthem« [Folk] • Scott Sedita: »WAR!!!« [Rock] • September Eleventh: »And A Nation Cried « / »Help Us Understand « / »If We All Unite« / »On Devil's Wings« / »Our Colors Will Never Run« / "Stand As One« / »The Day Thousands Died « / »Together In The End « / »We'll Keep On Shining « [New Country] • Stefanie Shea: »Song for New York, 9-11-01« [Alternative] - Shony: "September 11«[Pop] • Mark Silverman: »House Of Cards (WTC Song)« [Folk] • Smart Apple: »Freedom Rings« [Rock] - Kelly Smith: »Hey Terrorists (We're Gonna Take You Out)« [Folk] • Jennifer Starr \& Silver Spur: »Heroes And Angels (09-11-01 WTC Tribute) « [Country] • Virginia Summerville: »Doing It All For Allah« [Pop] • Spun: »Feel The Light (The Day The Towers Fell)« [Pop] • Spur of the Moment: »Terrorism - God Bless America« [Country] - Dave Stephens: »Cleared To Land « [Country] • Swing Academy: "September 11 « [Soft Rock] • The David First All-Moons: »Jump Back « [Pop] • The Front Porch Country Band: »The American Trilogy « [Country] • The Inside Out Band: »This Time America's Not Playing Around « [Country] • Dave Thomas with Charlene Peyton: »A New Cry For Freedom « [Country] - David Treadway: "Rock-A-Bye (World Trade Center Tribute)« [Pop] • Vagabond Missionaries: »9-11-01 Tears of America« [Rock] - Steve Vaus: »There's An Eagle« [Country] • Warren Wagner: »Out Of This Night« [Folk] • Frank >Flash« Woodburn: »I Am Freedom« / »Fear This (Home Of The Free)« [Metal] • Working Spliffs: »In A Cave« [Alternative] • Neil Zarcona: »Remember The World Trade Center« [Pop] 